\title{
Transfer of Peptostreptococcus parvulus (Weinberg, Nativelle, and Prévot 1937) Smith 1957 to the Genus Streptococcus: Streptococcus parvulus (Weinberg, Nativelle, and Prévot 1937) comb. nov., nom. rev., emend.
} ELIZABETH P. CATO

Department of Anaerobic Microbiology, Virginia Polytechnic Institute and State University, Blacksburg, Virginia 24061

\begin{abstract}
On the basis of increased fermentative ability when growth is stimulated by Tween 80, with the production of large amounts of lactic acid and only traces of acetic, succinic, or formic acid, it is proposed that Peptostreptococcus parvulus (Weinberg, Nativelle, and Prévot 1937) Smith 1957 be returned to the genus Streptococcus, where it was placed by the original authors. The description has been amended to reflect the increased biochemical activity of strains of this species when all media contain $0.02 \%$ Tween 80 . The type strain of Streptococcus parvulus (Weinberg, Nativelle, and Prévot 1937) comb. nov., nom. rev. (VPI 0546) has been deposited in the American Type Culture Collection as ATCC 33793.
\end{abstract}

Peptostreptococcus parvulus (Weinberg, Nativelle, and Prévot 1937) Smith 1957 was included in the 1980 Approved Lists of Bacterial Names (7), with VPI 0546 (Prévot 1246) cited as the type strain of the species. This strain had characteristics described for "Streptococcus parvulus" Weinberg, Nativelle, and Prévot 1937 (9) when tested in prereduced peptone-pepticase-yeast extract basal medium (2) to which various substrates had been added. Since the strain was obligately anaerobic and under these conditions of growth was nonfermentative, the species was placed in the genus Peptostreptococcus in the 7th edition of Bergey's Manual of Determinative Bacteriology (8). However, we report here that when Tween 80 was added to test media at a final concentration of $0.02 \%$, growth was markedly enhanced, and several carbohydrates were strongly fermented. This puts the present taxonomic position in doubt.

\section{MATERIALS AND METHODS}

Bacterial strains. The strains characterized were ATCC $33793^{\mathrm{T}}\left(\leftarrow\right.$ VPI $0546^{\mathrm{T}} \leftarrow$ IPP $1246^{\mathrm{T}}$, " Streptococcus parvulus") and VPI 11041 ( $\leftarrow$ IPP 1508, "Streptococcus parvulus"). Both were from the collection of A. R. Prévot, Institute Pasteur, Paris.

Methods. Characteristics of the two strains were determined by using prereduced, anaerobically sterilized media supplemented with hemin and vitamin $\mathrm{K}_{1}$ and anaerobic methods previously described (2). The basal medium contained (per $100 \mathrm{ml}$ ): $0.5 \mathrm{~g}$ of peptone (Difco Laboratories, Detroit, Mich.), $0.5 \mathrm{~g}$ of pepticase (enzymatic digest of casein; Humko Sheffield Chemical, Memphis, Tenn.), $1.0 \mathrm{~g}$ of yeast extract
(Difco Laboratories), $0.4 \mathrm{ml}$ of resazurin solution, 4.0 $\mathrm{ml}$ of mineral salts solution, and $0.05 \mathrm{~g}$ of cysteine $\mathrm{HCl} \cdot \mathrm{H}_{2} \mathrm{O}$ as described previously (2). Tubes were inoculated under a stream of oxygen-free $\mathrm{CO}_{2}$. A $10 \%$ $\mathrm{CO}_{2}-90 \% \mathrm{H}_{2}$ atmosphere was used for anaerobic incubation of plates in Brewer jars. Reactions were tested simultaneously in media with and without $0.02 \%$ Tween 80 (polyoxyethylene [20] sorbitan monooleate; J. T. Baker Chemical Co., Phillipsburg, N.J.). Susceptibilities to antibiotics were determined by the broth disk method of Wilkins and Thiel (10).

The guanine-plus-cytosine percentage of a preparation of deoxyribonucleic acid of strain ATCC $33793^{\mathrm{T}}$ was determined by a thermal melting point method previously described $(4,5)$.

\section{RESULTS AND DISCUSSION}

The morphology of the two strains was exactly as previously described (9). When Tween 80 was not present, carbohydrate media were not acidified, and only traces of lactic and acetic acids were detected by gas-liquid chromatography. These results agreed with those reported in the original description (9). However, growth was markedly enhanced in media supplemented with Tween 80. Furthermore, cellobiose, esculin, fructose, galactose, glucose, inulin, lactose, maltose, mannose, salicin, sucrose, and trehalose were strongly fermented, and erythritol and xylose were weakly fermented. The major product of the fermentation of glucose was lactic acid, with only trace amounts of acetic acid and sometimes of formic or succinic acid or both. Other biochemical reactions were the same by both test methods. 
The reactions of the two strains tested were identical and, because they were identified as Streptococcus parvulus by one of the authors of the original species description, they may be considered as representative of the species. Strains of the species have not been reported, possibly because when the nutritional requirements of the organisms were met, the characteristics found did not agree with those previously described $(2,9)$.

Anaerobic species have been included in the genus Streptococcus (3), as recommended by Rogosa (6), if they ferment carbohydrates with the production of major amounts of lactic acid. Therefore, it is proposed that the species Peptostreptococcus parvulus be transferred to the genus Streptococcus as Streptococcus parvulus.

Amended description of Streptococcus parvulus. Streptococcus parvulus (Weinberg, Nativelle, and Prévot 1937) nom. rev. (par'vu.lus. L. dim. adj. parvulus somewhat small). Obligately anaerobic, nonmotile, nonsporeforming, grampositive cocci; 0.3 to $0.6 \mu \mathrm{m}$ in diameter; occurring in short chains or occasionally in pairs. After incubation for 2 days on anaerobic supplemented brain heart infusion blood agar plates, colonies were minute to $1.0 \mathrm{~mm}$ in diameter, circular, entire, transparent, grayish, slightly peaked; blood was not hemolyzed; there was no visible growth on plates incubated in a candleextinction jar or in an aerobic atmosphere.

Cultural characteristics. Growth was markedly stimulated by the addition of $0.02 \%$ Tween 80 . Unless otherwise stated, all results presented here are from media containing Tween 80 . The optimum temperature for growth was $37^{\circ} \mathrm{C}$; growth was equally good at $45^{\circ} \mathrm{C}$ but barely visible at $25^{\circ} \mathrm{C}$. In carbohydrate broth media, there was slight turbidity and a smooth to flocculent sediment. Growth was completely inhibited in the presence of $20 \%$ bile or $6.5 \% \mathrm{NaCl}$. After 5 days of incubation in peptone-pepticase-yeast extract-glucose-Tween 80 broth, the $\mathrm{pH}$ of the cultures was 4.0 to 4.2 . When Tween 80 was omitted, the $\mathrm{pH}$ was 5.8 .

Biochemical reactions. Both strains produced acid (final $\mathrm{pH},<4.7$ ) from cellobiose, esculin, fructose, galactose, glucose, inulin, lactose, maltose, mannose, salicin, sucrose, and trehalose; erythritol and xylose were weakly fermented; no acid was produced from amygdalin, arabinose, glycerol, glycogen, inositol, mannitol, melezitose, melibiose, pectin, raffinose, rhamnose, ribose, sorbitol, or starch.

Esculin was hydrolyzed; neither starch nor hippurate was hydrolyzed.

Nitrate was not reduced. Indole was not formed.

A solid acid curd formed in milk; neither milk, gelatin, nor meat was digested.
Neither catalase, urease, deoxyribonuclease, lecithinase, nor lipase was detected.

Fermentation products. The fermentation acids detected in glucose broth cultures of strain ATCC $33793^{\mathrm{T}}$ after 5 days of incubation were (in milliequivalents per $100 \mathrm{ml}$ ): lactic acid, 7.3 to 8.4; acetic acid, 0.3; and succinic acid, 0.03.

Pyruvate was converted to acetate, but neither lactate nor threonine was utilized.

Neither hydrogen, ammonia, nor $\mathrm{H}_{2} \mathrm{~S}$ was produced. No gas was formed in glucose agar deeps.

Susceptibility to antimicrobial agents. Both strains were susceptible to chloramphenicol (12 $\mu \mathrm{g} / \mathrm{ml})$, clindamycin $(1.6 \mu \mathrm{g} / \mathrm{ml})$, erythromycin $(3 \mu \mathrm{g} / \mathrm{ml})$, penicillin $\mathrm{G}(2 \mathrm{U} / \mathrm{ml})$, and tetracycline $(6 \mu \mathrm{g} / \mathrm{ml})$.

Habitat. The source of these strains is not known, but Weinberg et al. reported (9) that the principal habitat was the respiratory tract.

Guanine-plus-cytosine content. The guanineplus-cytosine content of the deoxyribonucleic acid of strain ATCC $33793^{\mathrm{T}}$ was $46 \mathrm{~mol} \%$. Although the deoxyribonucleic acid base ratio of ATCC $33793^{\mathrm{T}}$ was high for members of the genus Streptococcus, Coykendall has reported base ratios of 44 to $46 \mathrm{~mol} \%$ in $S$. sobrinus and 43 to $45 \mathrm{~mol} \%$ in $S$. ferus (1).

\section{Type strain. ATCC 33793 (= VPI 0546).}

Fermentation of inulin in the presence of Tween 80 , failure to ferment glucose or sucrose in the absence of Tween 80 , and lack of oxygen tolerance for growth help to differentiate this species from those which it most closely resembles, viz. $S$. anginosus, $S$. intermedius, and $S$. morbillorum.

\section{ACKNOWLEDGMENTS}

I thank John L. Johnson for determining the base ratio of ATCC 33793, Leesa Miller for excellent technical assistance, and Lillian V. Holdeman and W. E. C. Moore for suggestions and critical reading of this paper.

This work was supported by Public Health Service grant DE 05139 from the National Institute of Dental Research and project 2022820 from the Commonwealth of Virginia.

\section{LITERATURE CITED}

1. Coykendall, A. L. 1977. Proposal to elevate the subspecies of Streptococcus mutans to species status, based on their molecular composition. Int. J. Syst. Bacteriol. 27:26-30.

2. Holdeman, L. V., E. P. Cato, and W. E. C. Moore (ed). Anaerobe laboratory manual, 4th ed. Anaerobe Laboratory, Virginia Polytechnic Institute and State University, Blacksburg, Va.

3. Holdeman, L. V., and W. E. C. Moore. 1974. New genus, Coprococcus, twelve new species, and emended descriptions of four previously described species of bacteria from human feces. Int. J. Syst. Bacteriol. 24:260-277.

4. Johnson, J. L., and C. S. Cummins. 1972. Cell wall composition and deoxyribonucleic acid similarities among the anaerobic coryneforms, classical propionibacteria, and strains of Arachnia propionica. J. Bacteriol. 109:10471066. 
5. Marmur, J., and P. Doty. 1962. Determination of the base composition of deoxyribonucleic acid from its thermal denaturation temperature. J. Mol. Biol. 5:109-118.

6. Rogosa, M. 1971. Peptococcaceae, a new family to include the gram-positive anaerobic cocci of the genera Peptococcus, Peptostreptococcus, and Ruminococcus. Int. J. Syst. Bacteriol. 21:234-237.

7. Skerman, V. B. D., V. McGowan, and P. H. A. Sneath. 1980. Approved lists of bacterial names. Int. J. Syst. Bacteriol. 30:225-420.
8. Smith, L. DS. 1957. Genus V. Peptostreptococcus Kluyver and van Niel 1936, p. 533-541. In R. S. Breed, E. G. D. Murray, and N. R. Smith (ed.), Bergey's manual of determinative bacteriology, 7 th ed. The Williams \& Wilkins Co., Baltimore.

9. Weinberg, M., R. Nativelle, and A. R. Prévot. 1937. Les microbes anaerobies. Masson and Co., Paris.

10. Wilkins, T. D., and T. Thiel. 1973. A modified broth-disk method for testing the antibiotic susceptibility of anaerobic bacteria. Antimicrob. Agents Chemother. 3:350-356. 